Egyptian Journal of Aquatic Biology \& Fisheries

Zoology Department, Faculty of Science,

Ain Shams University, Cairo, Egypt.

ISSN $1110-6131$

Vol. 25(5): 769 - 786 (2021)

www.ejabf.journals.ekb.eg

\title{
Biodiversity and Distribution of Macrobenthic Invertebrate Community in Lake Nasser, Egypt
}

\author{
Marian G. Nassif \\ National Institute of Oceanography and Fisheries (NIOF), Egypt \\ george.marian@hotmail.com
}

\begin{abstract}
ARTICLE INFO
Article History:

Accepted: Oct. 26, 2021

Online: Nov. 19, 2021

Keywords:

Lake Nasser,

Macrobenthos,

Invertebrates,

Biodiversity,

Long-term Changes
\end{abstract}

Received: Sept. 30, 2021

ABSTRACT

Lake Nasser is a vast reservoir in southern Egypt and northern Sudan and one of the largest man-made lakes in the world. It has vital importance to Egypt because of the safe water supply of the country. Therefore, the water quality of the lake must be continuously monitored to cope with the challenges of water scarcity and a healthy water supply. Thus, fifteen stations were selected to represent the different habitats of the whole lake in March and July 2019. 9 species of macrobenthic fauna were identified, representing three phyla: Annelida, Arthropoda, and Mollusca with percentages of $74.62 \%, 15.41 \%$ and $9.97 \%$, respectively. The total recorded density was 863 org. $/ \mathrm{m}^{2}$ and the highest densities were recorded in the southern sectors of the lake. Summer (flood season) exhibited the highest population density.The western station of EL Madiq sector showed the highest Shannon Weaver diversity index $\left(\mathrm{H}^{\prime}=\right.$ 1.55), which could be attributed to the dominance of 4 species of arthropods, and exclusively, the dominance of nymphs of Ischneura. Contrarily, the middle stations of Wadi Abyad and Aswan sectors recorded the least diversity Shannon Weaver index value $\left(\mathrm{H}^{\prime}=0.21\right.$ and 0.27 , respectively) which may be attributed to the nature of the sediment which led to the absence of all mollusk species and the presence of one annelid species (Limnodrilus sp.) and one insect species (Chironomuslarvae). The present study revealed that the number of species decreased dramatically to 9 species compared to $15,43,39$, and 24 recorded in 1987, 1993, 1995, and 2014, respectively. It is recommended to force an effective legal framework to mitigate pollution in Lake Nasser.

\section{INTRODUCTION}

Between January 1964 and June 1968, the High Dam of Aswan was built, creating Lake Nasser (Abd El-Monsefet al., 2015; El Gamal\&Zaki, 2017; Salihet al., 2019). The Lake's area is roughly $5000 \mathrm{~km} 2$ (Farhat\&Aly, 2018). It has a large water storage capacity of 150-165 km and can handle up to $11,000 \mathrm{~m} 3 / \mathrm{s}$ of water flow. Lake Nasser has a mean depth of 90 meters and a maximum width of 60 kilometers (Abou El Ella \& El Samman, 2010; El Shemy, 2010; Khalifaet al., 2015).

Latif (1974) and Iskaros $(\mathbf{1 9 8 8 ,}$ 1993) reported that macrobenthic invertebrates are significant food sources for a variety of fish species in Lake Nasser. Macrobenthic invertebrates 
are better bio-indicators for comprehending the changing aquatic conditions compared to the chemical and microbiological data, which only provide short-term variations (Ravera, 1998, 2000). However, knowledge on Lake Nasser's invertebrates is scarce. Iskaros (1988, 1993) investigated the distribution and seasonal changes of benthic creatures in Lake Nasser, identifying 40 species in the Aquatic Insecta, Mollusca, Annelida, and Platyhelminthes. Fishar (1995)discovered 39 different macrobenthic species. Whereas, only nine species of Arthropoda, Annelida, and Mollusca were discovered in the main channel (El-Shabrawy and Abd El-Regal, 1999). During spring, summer, autumn, and winter of 2009, Iskaros and Gindy (2009) investigated the influence of the substrate quality on the benthic fauna in Aswan reservoir. On the other hand, Mola and Abdel-Gawad (2014) addressed the spatial and the temporal variations of macrobenthic fauna in Lake Nasser khors in 2013, and discovered that the maximum population density was found in Tushka west Khor, while the lowest was found in Khor WadiAbyad. The afore-mentined authors added that, in comparison to the other seasons, spring recorded the highest population density. Abdel-Gawad and Mola (2014) found 24 macrobenthic invertebrate species in Lake Nasser's main stream in 2013. Furthermore, AbdelGawad (2016) investigated the influence of physico-chemical variables on the distribution and diversity of molluscs in Lake Nasser, recording 10 different species, seven of them were Gastropod while three were bivalves. Wahab et al. (2018) investigated the community structure, abundance, and diversity of macrobenthic invertebrates in four Northern khors of Lake Nasser during 2015. They found 26 species, with the western khors having a higher diversity and quantity of species than the eastern khors. Abdel Gawad and Abdel-Aal (2016) examined the community structure of phytoplankton and macrobenthic invertebrates linked with the macrophyte Myriophyllum spicatum in the Dahmeit and Tushka west khors of Lake Nasser during the pre-flood, flood and post-flood seasons.

Obviously, there is no enough data on the mainstream of Lake Nasser's bottom fauna which is considered one of the main components of the food web and a source of fish diet. Thus, this investigation was dedicated to monitor the macrobenthic invertebrate groups inhabiting the mainstream of Lake Nasser (distribution, abundance and diversity of macrobenthic invertebrates in relation to different physico-chemical parameters and seasonal variation). Additionally,, it aimed to spotlight on the impact of the flood on the bottom fauna.

\section{MATERIALS AND METHODS}

\section{The study area}

Fifteen stations were selected to represent the different habitats of the whole lake (Fig. 1). These stations can be described as five sectors (Aswan High Dam, WadiAbyad, El-Madiq, Tushka, and Abu Simble). Samples were collected from the east, middle and west of each sector. 


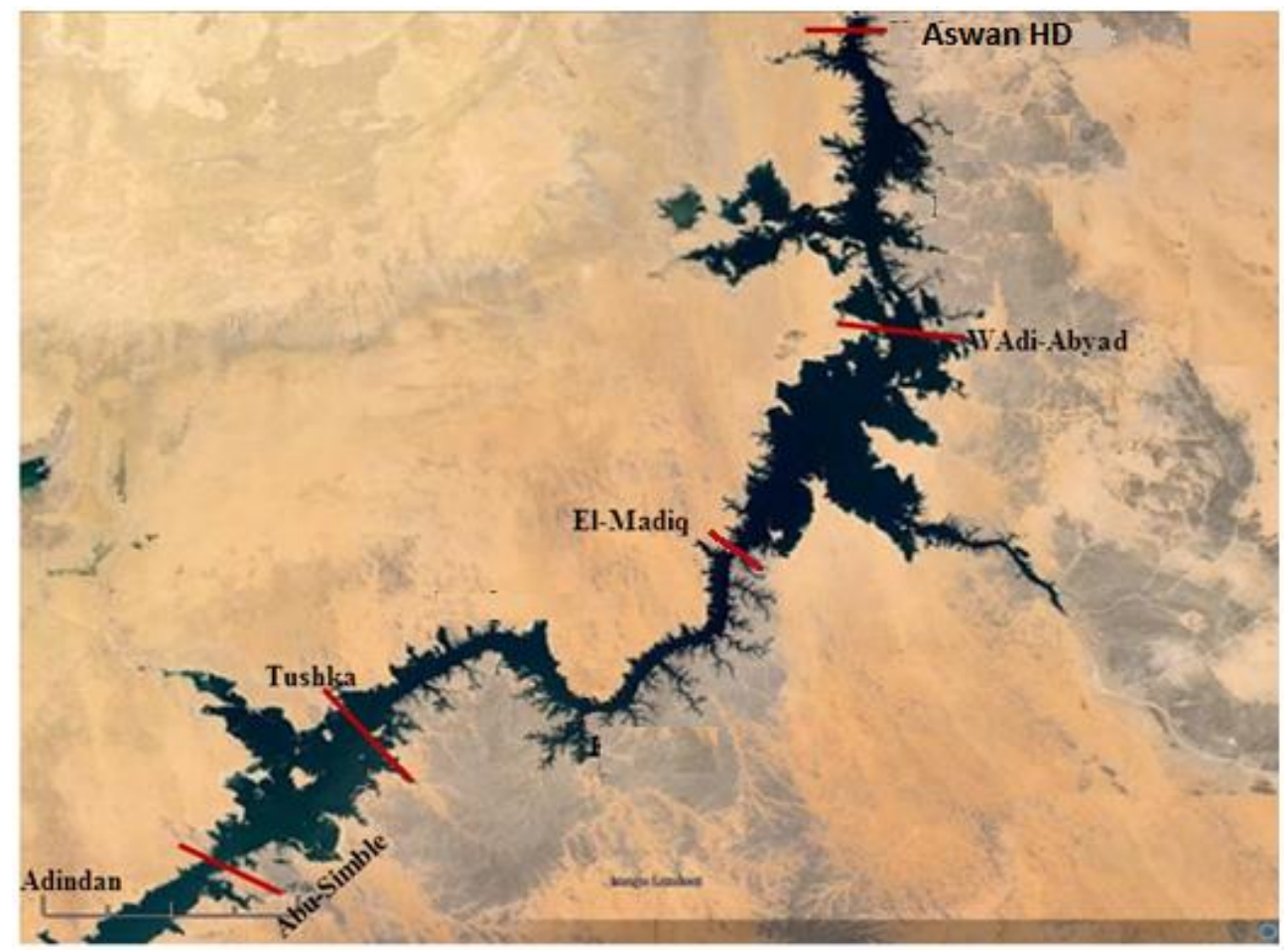

Fig. 1. A map of Lake Nasser showing the selected sampling sectors

\section{Sampling procedures}

Water and macrobenthic faunal samples were collected from Lake Nasser in March and July 2019 (before and during the flood of 2019). Samples' analyses were carried out following the Standard Methods for Examination of Water and Waste Water (APHA, 2005).

Water temperature, electrical conductivity(EC), hydrogen ion concentration $(\mathrm{pH})$ and dissolved oxygen (DO) were measured in the field using multi-probe portable meter (WTW Model Oxi 197). Water transparency was measured using a standard Secchi disc of $25 \mathrm{~cm}$ diameter. The observations were made in the field and the results were expressed in $\mathrm{cm}$ at the distance in which the Secchi disc disappeared.

The Macrobenthic faunal samples were collected by a square Ekman grab sampler with an opening area of $225 \mathrm{~cm}^{2}$. The samples were taken from the surface layer of the bottom deposits of each station. Each sample was washed immediately to remove any adhering sediments or mud using $500 \mu \mathrm{m}$ mesh net and stored in plastic containers with $5 \%$ formalin as a preservative. In the laboratory, the samples were washed and sieved again through a net with $500 \mu \mathrm{m}$ mesh size. Benthic animals were sorted to genera and species level using a zoom stereo microscope. Each group was counted and preserved in a glass bottle with $7 \%$ formalin. Identification of the collected species was carried out according to the studies of Brown (1980), Ruffo (1982), ElShimy (1994) and Ibrahim et al. (1999).

\section{Data treatments and statistical analysis}

The data were adjusted to correlation analysis was using Excel to study the relationship between biotic and abiotic factors. Species diversity of bottom fauna was calculated and evaluated to assess the impact of pollution on the degradation of species diversity, food chains, 
and eventually the ecosystem using a computer software Primer 5 version 5.2.0. The similarity was determined between the communities of macroinvertebrates in the fifteen stations of Lake Nasser using Bray-Curtiz similarity index.

\section{RESULTS AND DISCUSSION}

\section{Physical and chemical variables}

\section{Water temperature}

Remarkably, temperature has a direct effect on aquatic organisms as well as on the chemical and physical characteristics (Abdo, 2003). Therefore, global warming has a great negative effect on aquatic organisms' diversity. The big difference in the temperature of Lake Nasser water along the year-round is considered as a controlling factor related to a range of species tolerance (Mageed \& Heikal, 2006). During the current study, there was no significant difference in water temperature between all stations with an annual average of $25^{\circ} \mathrm{C}($ Table 1$)$.

\section{Water transparency}

The higher the turbidity, the lower the light penetration is. This, in turn, affects photosynthesis and many other vital processes. During the current investigation, the northern part of the lake shows the highest transparency, especially in Aswan sector with an annual average of $318 \mathrm{~cm}$. The lake's transparency gradually decreased downward to reach its lowest values in Tushka sector with an annual average of $215 \mathrm{~cm}$. No significant effect of water transparency was detected on the distribution of the benthic fauna, as shown in the correlation study (Table 1).

\section{Electrical conductivity (EC)}

During the period of investigation, the electrical conductivity (EC) values showed their highest in the eastern part of Aswan sector in March (before flood), with an average of 291 $\mathrm{mS} / \mathrm{cm}$. It was noticeable that, EC values were gradually decreased from the north to the south of the lake with an average of $259 \mathrm{mS} / \mathrm{cm}$ (Table 1).Similar results were recorded by Mageed and Heikal (2006). There was no significant correlation between EC values and the macrobenthic invertebrates' biodiversity or distribution.

\section{Hydrogen ion concentration (pH)}

Hydrogen ion concentration $(\mathrm{pH})$ is one of the most crucial operational water quality parameters (WHO, 2003). During the present study, there was no significant difference between stations along the lake. Furthermore, the $\mathrm{pH}$ values were in the alkaline side, recording an average of 8.6 (Table 1).

\section{Dissolved Oxygen (DO)}

The peak of the dissolved oxygen values in Lake Nasser was detected in Tushka sector with an average of $7 \mathrm{mg} / \mathrm{l}$. Furthermore, the western part of Tushka sector exhibited the highest DO concentration in March $(9.6 \mathrm{mg} / \mathrm{l})$. On the other hand, El-madiq and Abu Simble revealed the lowest DO concentration in summer $(5.3 \mathrm{mg} / \mathrm{l})$. However, Wadi Abyad sector showed the lowest annual DO with an average of $6.4 \mathrm{mg} / \mathrm{l}$ (Table 1). Generally, Lake Nasser showed a good status in DO, according to the Egyptian Governmental Decree No.92/2013. 
Table 1,Spatio-temporal variation of physico-chemical parameters of Lake Nasser during March and July 2019

\begin{tabular}{|c|c|c|c|c|c|c|c|c|c|c|c|c|c|c|c|c|c|c|c|c|}
\hline & M1E & M1M & M1W & Aswan & M2E & $\mathrm{M} 2 \mathrm{M}$ & $\mathrm{M} 2 \mathrm{~W}$ & $\begin{array}{c}\text { WadiAb } \\
\text { yad }\end{array}$ & M3E & M3M & M3W & $\begin{array}{c}\text { El- } \\
\text { Madiq }\end{array}$ & M4E & M4M & M4W & Tushka & M5E & M5M & $\begin{array}{c}\text { M5 } \\
\text { W }\end{array}$ & $\begin{array}{c}\text { Abu } \\
\text { Simble }\end{array}$ \\
\hline \multicolumn{21}{|l|}{$\begin{array}{c}\text { Temp } \\
\text { oC }\end{array}$} \\
\hline March & 18.9 & 17.8 & 17.5 & 18 & 19.6 & 19.9 & 20.3 & 20 & 20.2 & 20.7 & 20.1 & 20 & 20.9 & 20.1 & 20.6 & 21 & 21.1 & 21.3 & 21.4 & 21 \\
\hline July & 28.2 & 26.7 & 26.7 & 27 & 30 & 29.7 & 30.3 & 30 & 31.1 & 31.1 & 31.1 & 31 & 31.4 & 31.2 & 30.9 & 31 & 30.6 & 30.6 & 31.3 & 31 \\
\hline Average & 24 & 22 & 22 & 23 & 25 & 25 & 25 & 25 & 26 & 26 & 26 & 26 & 26 & 26 & 26 & 26 & 26 & 26 & 26 & 26 \\
\hline \multicolumn{21}{|l|}{$\begin{array}{c}\text { Trans } \\
\text { cm }\end{array}$} \\
\hline March & 400 & 300 & 310 & 337 & 250 & 400 & 390 & 347 & 250 & 240 & 280 & 257 & 190 & 230 & 220 & 213 & 180 & 180 & 185 & 182 \\
\hline July & 250 & 300 & 350 & 300 & 180 & 310 & 220 & 237 & 270 & 200 & 330 & 267 & 220 & 250 & 180 & 217 & 280 & 280 & 305 & 288 \\
\hline Average & 325 & 300 & 330 & 318 & 215 & 355 & 305 & 292 & 260 & 220 & 305 & 262 & 205 & 240 & 200 & 215 & 230 & 230 & 245 & 235 \\
\hline \multicolumn{21}{|l|}{$\begin{array}{c}\mathrm{EC} \\
\mathrm{mS} / \mathrm{cm}\end{array}$} \\
\hline March & 291 & 286 & 282 & 286 & 285 & 283 & 283 & 284 & 276 & 278 & 285 & 280 & 264 & 261 & 261 & 262 & 254 & 257 & 257 & 256 \\
\hline July & 246 & 250 & 248 & 248 & 247 & 246 & 247 & 247 & 244 & 245 & 250 & 246 & 237 & 238 & 234 & 236 & 240 & 243 & 237 & 240 \\
\hline Average & 269 & 268 & 265 & 267 & 266 & 265 & 265 & 265 & 260 & 262 & 268 & 263 & 251 & 250 & 248 & 249 & 247 & 250 & 247 & 248 \\
\hline \multicolumn{21}{|l|}{ pH } \\
\hline March & 8.45 & 8.39 & 8.37 & 8.40 & 8.61 & 8.54 & 8.49 & 8.55 & 8.77 & 8.79 & 8.77 & 8.8 & 8.72 & 8.79 & 8.7 & 8.7 & 8.85 & 8.84 & 8.71 & 8.8 \\
\hline July & 8.49 & 8.6 & 8.58 & 8.56 & 8.5 & 8.51 & 8.52 & 8.51 & 8.71 & 8.66 & 8.44 & 8.6 & 8.55 & 8.57 & 8.74 & 8.6 & 8.43 & 8.47 & 8.56 & 8.5 \\
\hline Average & 8.47 & 8.50 & 8.475 & 8.48 & 8.56 & 8.525 & 8.505 & 8.53 & 8.74 & 8.725 & 8.605 & 8.7 & 8.64 & 8.68 & 8.72 & 8.7 & 8.64 & 8.66 & $\begin{array}{l}8.6 \\
35\end{array}$ & 8.6 \\
\hline \multicolumn{21}{|l|}{$\begin{array}{r}\mathrm{DO} \\
\mathrm{mg} / \mathrm{l}\end{array}$} \\
\hline March & 7.27 & 8.83 & 6.25 & 7.45 & 6.88 & 6.95 & 8.08 & 7.3 & 8.62 & 8 & 8.67 & 8.4 & 7.39 & 8.9 & 9.6 & 8.6 & 9.28 & 6.98 & 8.7 & 8.3 \\
\hline July & 5.85 & 5.48 & 6.34 & 5.89 & 6.05 & 5.15 & 5.38 & 5.5 & 5.74 & 4.9 & 5.13 & 5.3 & 5.2 & 5.09 & 5.8 & 5.4 & 5.52 & 5.5 & $\begin{array}{c}5.0 \\
2\end{array}$ & 5.3 \\
\hline Average & 6.56 & 7.16 & 6.295 & 6.67 & 6.47 & 6.05 & 6.73 & 6.42 & 7.18 & 6.45 & 6.9 & 6.84 & 6.30 & 7.00 & 7.7 & 7.0 & 7.4 & 6.24 & $\begin{array}{c}6.8 \\
6\end{array}$ & 6.8 \\
\hline
\end{tabular}

\section{Macrobenthic fauna}

\section{Population density and community structure}

Nine macrobenthic invertebrate species were found during the period of study. They represent three phyla; namely, Annelida, Arthropoda, and Mollusca with the percentage of $74.62 \%, 15.41 \%$, and $9.97 \%$, respectively (Fig. 2). A similar result was recorded in the study of Mola and Abdel Gawad (2014). During the present study, the total density of the macrobenthos was $863 \mathrm{org} . / \mathrm{m}^{2}$ (Table 2). It was noticed that the community represented a higher 
density at the eastern sector of the lake during spring (pre-flood); while the density was higher in the middle of the lake during summer (flood season).

The highest population densities were found in the southern part of the lake, particularly in Tushka and Abu Simble sectors, with averages of 1340 and $1065 \mathrm{org} / \mathrm{m}^{2}$, respectively (Fig. 3). This result is in coincidence with that of Abdel Gawad and Mola (2014). This finding may be attributed to the nature of the bottom sediments and the availability of food supply forming the most significant factor that determines the macrobenthos distribution (Iskaros \& El-Dardir, 2010). On the oher hand, Nkwojiet al. (2010) found that low abundance and diversity of macrobenthos community were greatly affected by stress imposed by land-based pollutants. In this context, El-madiq sector revealed the poorest population density with an annual average of $445 \mathrm{org} . \mathrm{m}^{2}$; a finding that matches with that of Abdel-Gawad and Mola (2014) who recorded $127 \mathrm{org} . / \mathrm{m}^{2}$ in El-madiq sector during their survey in 2013.

Regarding the seasonal variation, summer (flood season) exhibited higher population density compared to spring (pre-flood) which was due to the dominance of Limnodrillus spp. and Chironomus larvae (Fig. 4). This result coincides with that of Iskaros and Gindy (2009) who referred this result to the strong relationship between the benthic fauna standing crop and the amount of organic carbon and calcium carbonate in the sediment. Furthermore, Latif $\boldsymbol{e t}$ al. (1979) mentioned that the macrobenthos standing crop increases with the rise of water level (flood season).

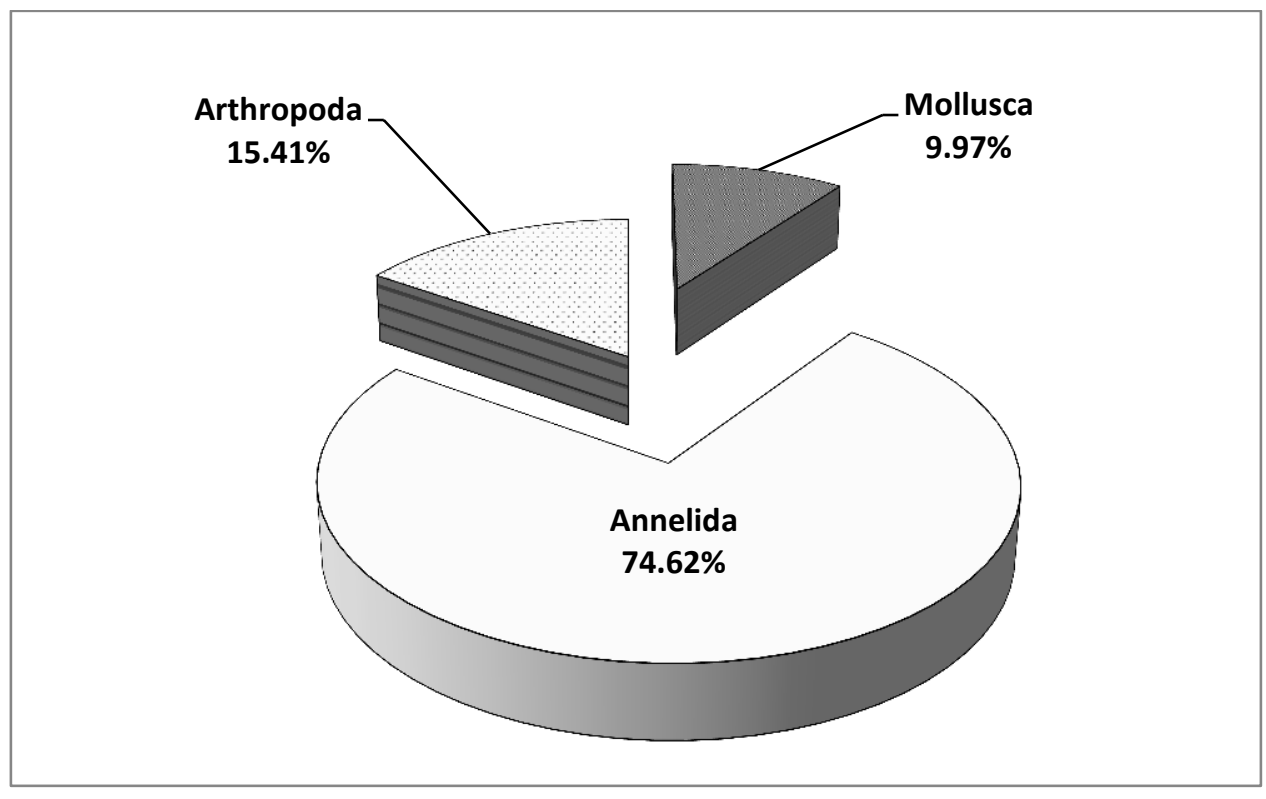

Fig. 2. Community structure of macrobenthic invertebrates in Lake Nasser in 2019 


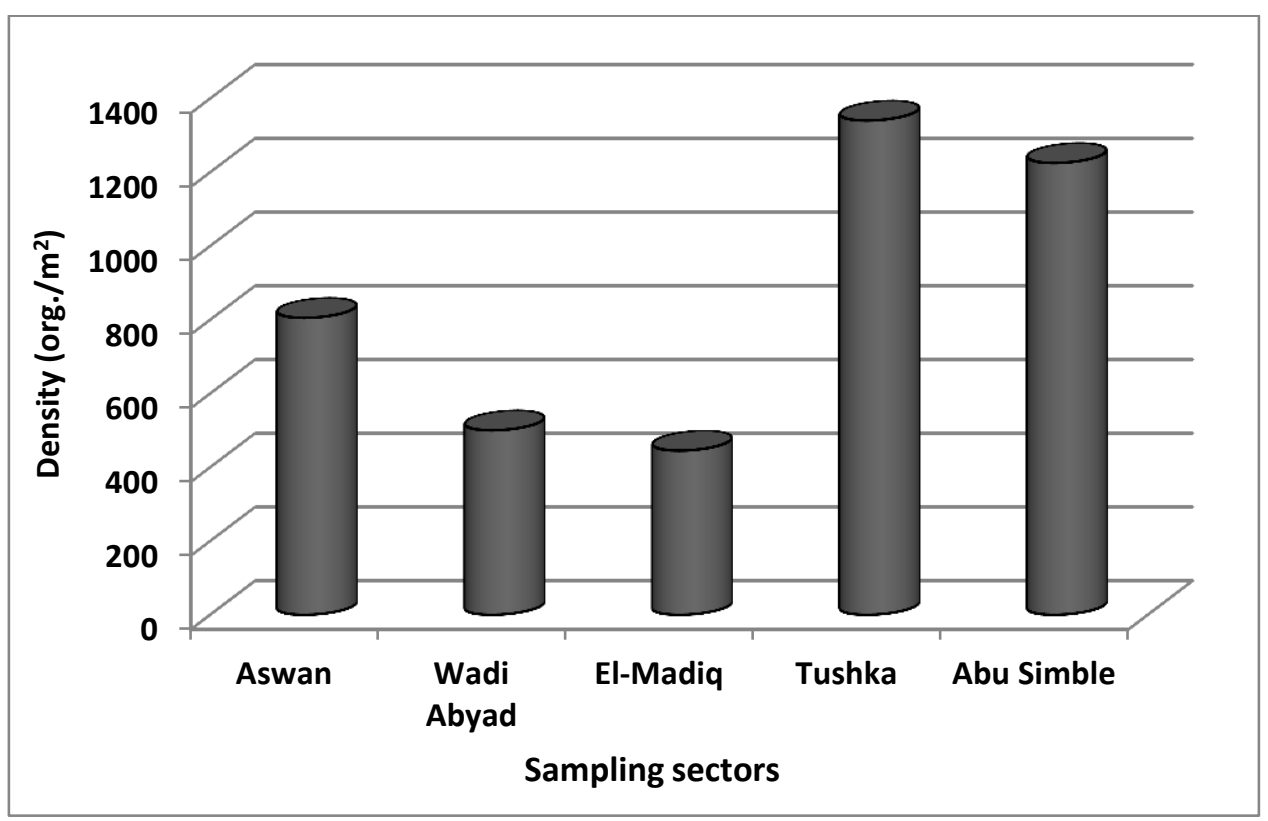

Fig. 3. Spatial distribution of macrobenthic invertebrates in Lake Nasser during March and July 2019.

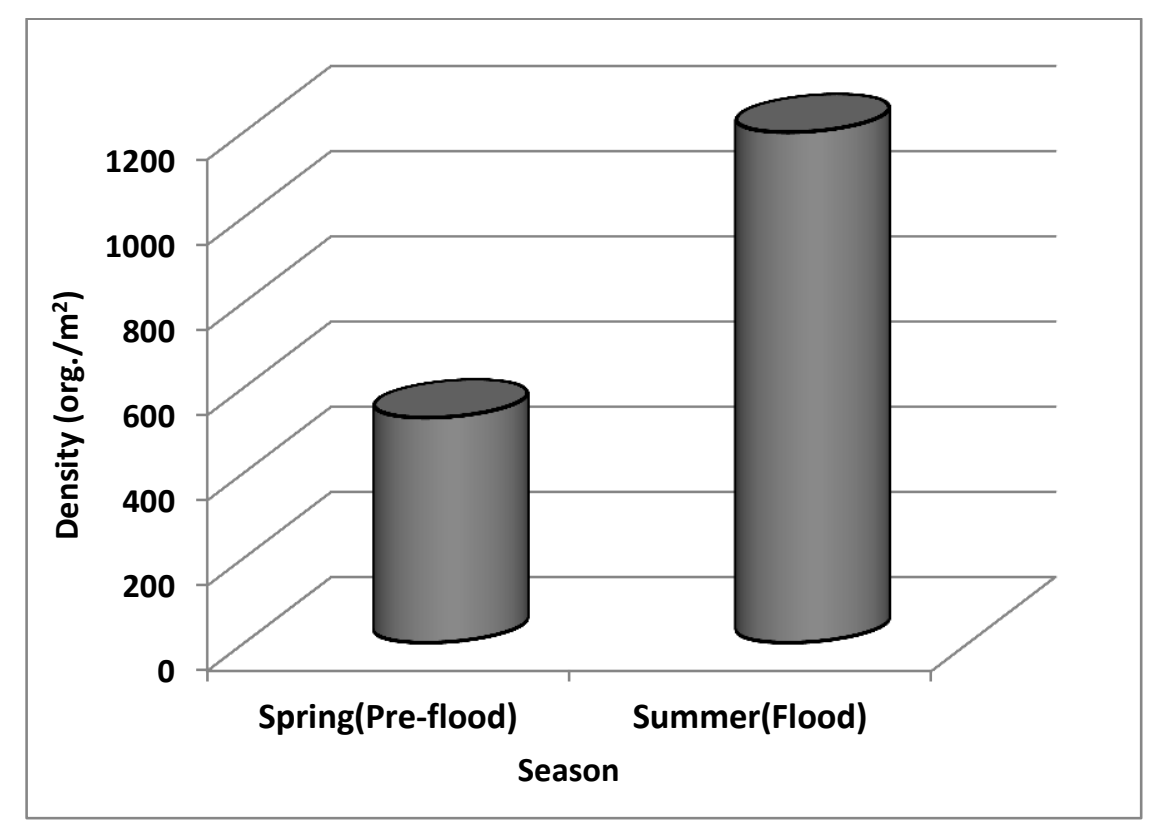

Fig. 4. Seasonal distribution of macrobenthic invertebrates in Lake Nasser during March and July 2019

\section{Species composition of Annelida}

Annelida was the most dominant macrobenthic invertebrates during the investigation period recording an annual average of $644 \mathrm{org} . / \mathrm{m}^{2}$ (Table 2). It contributed about $74.62 \%$ of the total macrobenthic invertebrates' community. It was represented only by one species; Limnodrilus sp. Iskaros and El-Dardir (2010) reported that, the predominance of oligochaetes 
in Lake Nasser was due to their ability to adapt to various habitats and their tolerance to low oxygen content or anoxic conditions. Moreover, the dominance of Limnodrilus sp. is similar to that reported in the study of Iskaros (1993), Fishar (1995), Iskaros and Dardir (2010), AbdelGawad and Mola (2014) and Mola and Abdel Gawad (2014).

For the distribution of Limnodrilus sp., the middle station of Abu Simble sector exhibited the highest population density, with an annual average of $1500 \mathrm{org} . / \mathrm{m}^{2}$. While, the middle station of El-Madiq sector exhibited the lowest population density with an annual average of 75 org. $/ \mathrm{m}^{2}$ (Fig. 5). It is worth mentioning that,the sectors of Abu Simble and Tushka revealed the highest Limnodrilus sp. population density with an annual average of 1065 and $1030 \mathrm{org} . / \mathrm{m}^{2}$, respectively.

With respect to seasonal variation, summer (flood season) exhibited the highest population density (902 org. $/ \mathrm{m}^{2}$, while spring (pre-flood season) exhibited the lowest density $\left(386 \mathrm{org} . / \mathrm{m}^{2}\right.$ ).

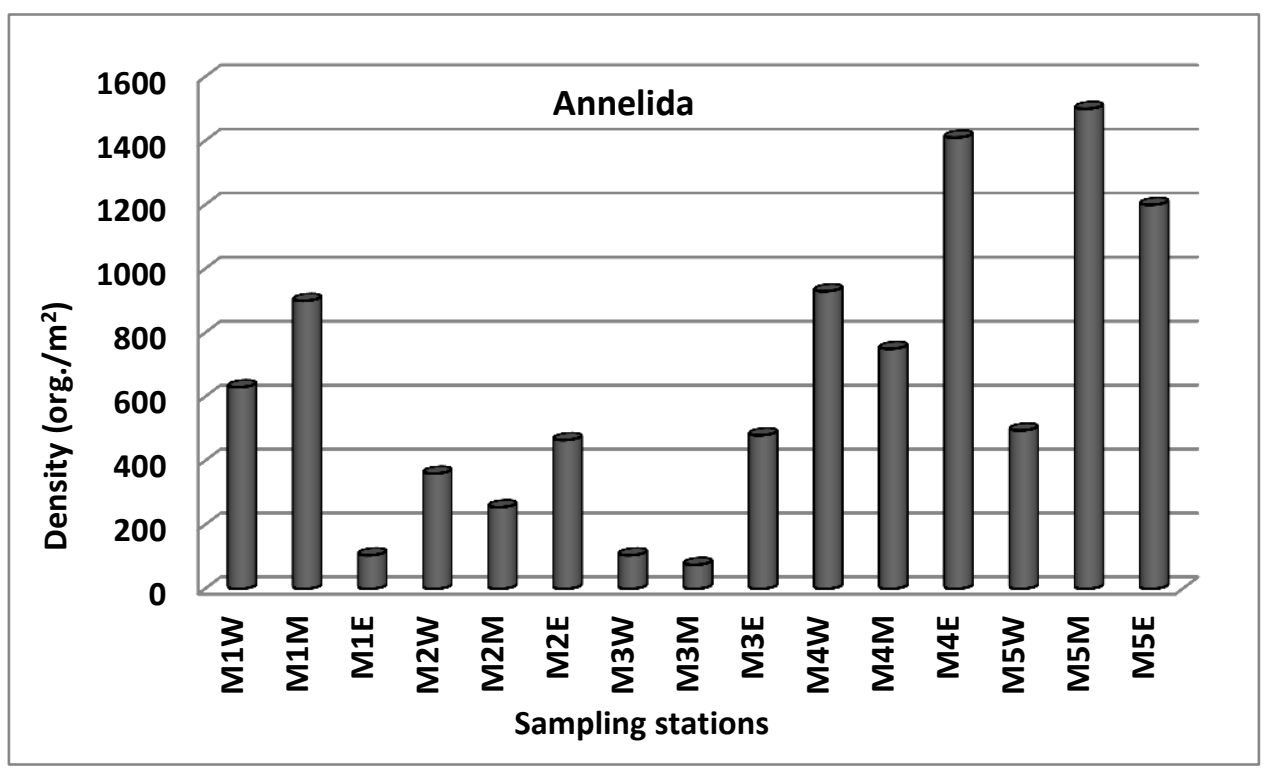

Fig. 5. Spatial distribution of Annelida in Lake Nasser during March 2019 and July 2019

\section{Species composition of Arthropoda}

Arthropods were ranked as the second dominant benthic fauna during the period of study with an annual average of 133 org. $/ \mathrm{m}^{2}$ (Table 2). It contributed about $15.41 \%$ of the total macrobenthic invertebrates' community. It was represented by Cricotopus sp., nymph of Ischneura larvae, and pupae of Chironomus sp. as shown in Fig. (6).

For spatial distribution, the maximum arthropod population density was represented in the western side of Aswan sector due to the dominance of Chironomus larvae with an annual average of $555 \mathrm{org} . / \mathrm{m}^{2}$, while the middle station of Wadi Abyad revealed the least population density with an annual average of $15 \mathrm{org} . / \mathrm{m}^{2}$ as shown in Fig. (7).

With respect to seasonal variation, summer (flood season) showed the highest population density with an average of $194 \mathrm{org} . / \mathrm{m}^{2}$, while spring (pre-flood season) revealed the least population density with an average of $72 \mathrm{org} . / \mathrm{m}^{2}$ (Table 2 ). 


\section{Chironomus larvae}

Chironomid larvae serve as the main food items for Mormyruskannume, M. caschive, and Chrysichthysauratus in Lake Nasser (Latif, 1974; Iskaros, 1988; Iskaros, 1993). During the present investigation, Chironomus larvae formed $74.44 \%$ of total arthropod density and $11.47 \%$ of total benthic invertebrates, with an annual average of $99 \mathrm{org} . / \mathrm{m}^{2}$. Chironomus larvae ranked as one of the highest population densities during the whole period of the current investigation. This agrees with the results recorded in the study of Fishar (2000). These larvae prefer to inhabit littoral zones of both oligotrophic and eutrophic lakes. The dominance of Chironomids in reservoirs is often an indicator of pollution as they can utilize organic matter and live under anoxic conditions (Rosenberg $\boldsymbol{e t}$ al., 1984). During the present study, the maximum population density was recorded in the western station of Aswan sector with an annual average of 540 org. $/ \mathrm{m}^{2}$. It was noticeable that Chironomus larvae disappeared from the middle stations of Wadi Abyad and Abu Simble sectors. This could be attributed to the fact that, the abundance and dominance of Chironomus larvae are related to macrophytes in order to avoid predators and feed on epiphytic microorganisms (Iskaros et al.,2011).

For seasonal variation, summer (flood season) revealed the highest population density with an average of $154 \mathrm{org} . / \mathrm{m}^{2}$. Similar results were found in the study of Iskaros $(\mathbf{1 9 8 8}, \mathbf{1 9 9 3})$. On the other hand, spring (pre-flood season) showed the lowest population density with an average of $44 \mathrm{org} . / \mathrm{m}^{2}$.

\section{Species composition of Mollusca}

Mollusca occupied the third rank of the benthic fauna of Lake Nasser, and it was represented by five species (Fig. 8). Gyraulusehrenbergi was the most dominant mollusk species during March (pre- flood season), while Succinia sp. was the most dominant species during July (flood season).

Generally, Gyraulusehrenbergi was the dominant species during the period of investigation and represented $43.02 \%$ of the total mollusk community.

With respect to spatial distribution, a significant spatial distribution was detected where the western sector of Tushka revealed the highest population density with an average of $465 \mathrm{org} . / \mathrm{m}^{2}$. On the other hand, molluscs disappeared completely from Abu Simble sector during the period of investigation (Fig. 9). 


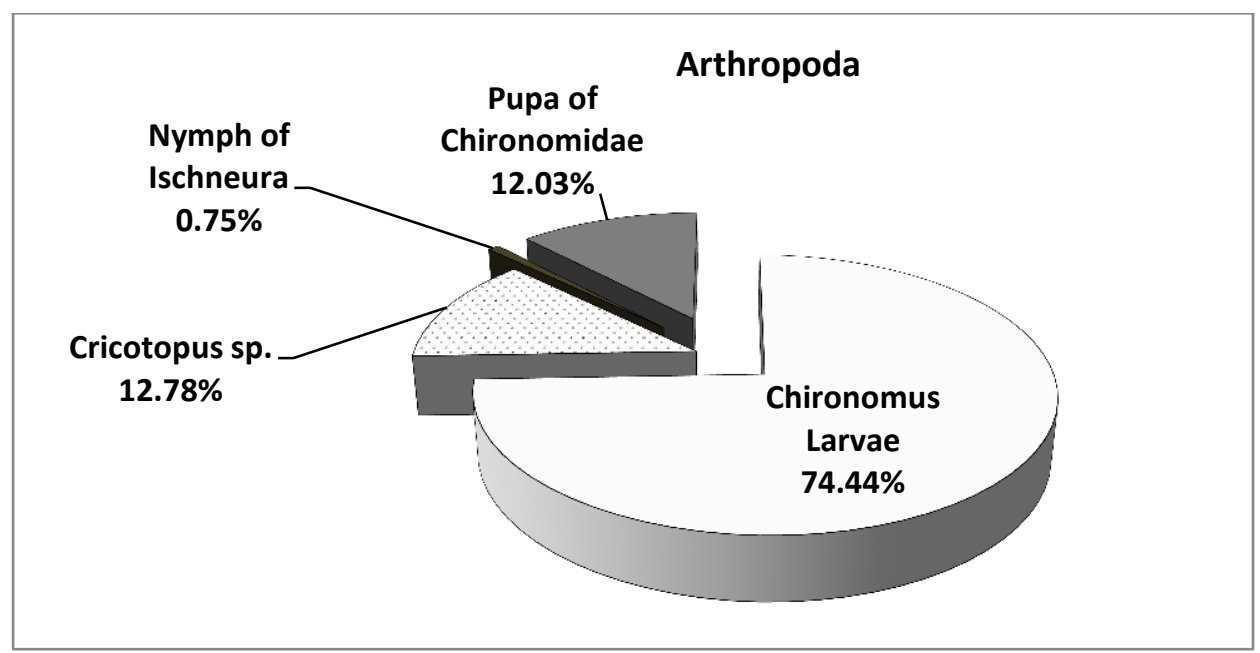

Fig. 6. Community structure of Arthropoda in Lake Nasser in 2019

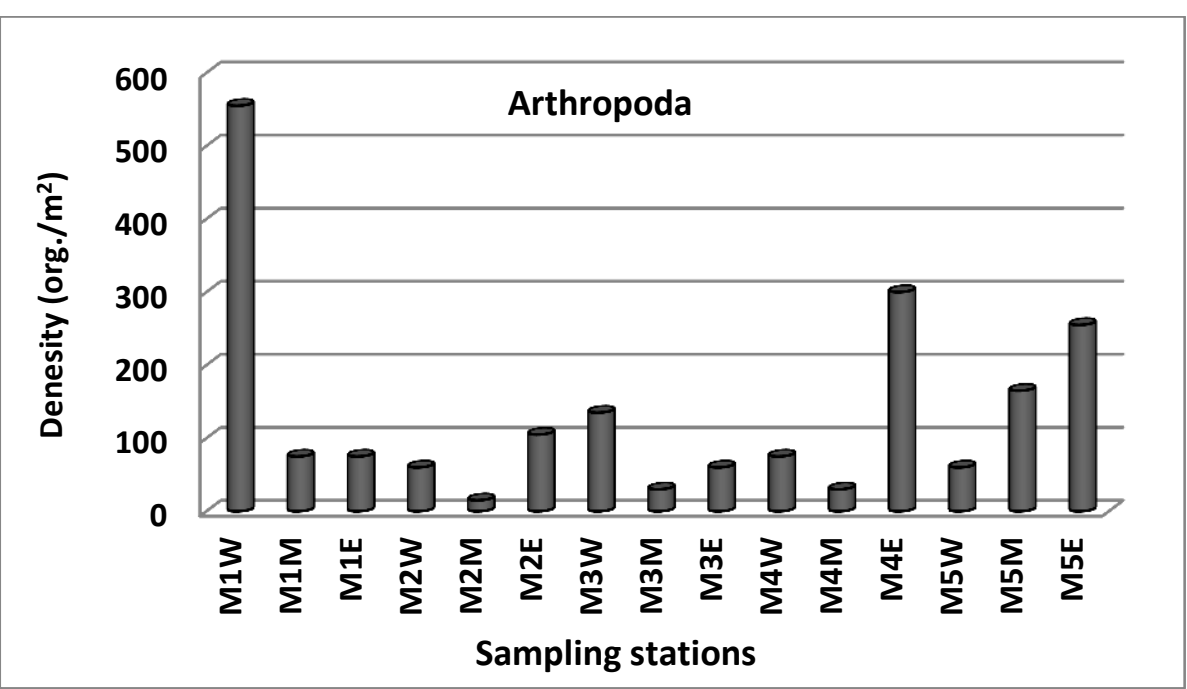

Fig. 7. Spatial distribution of Arthropoda in Lake Nasser during March 2019 and July 2019

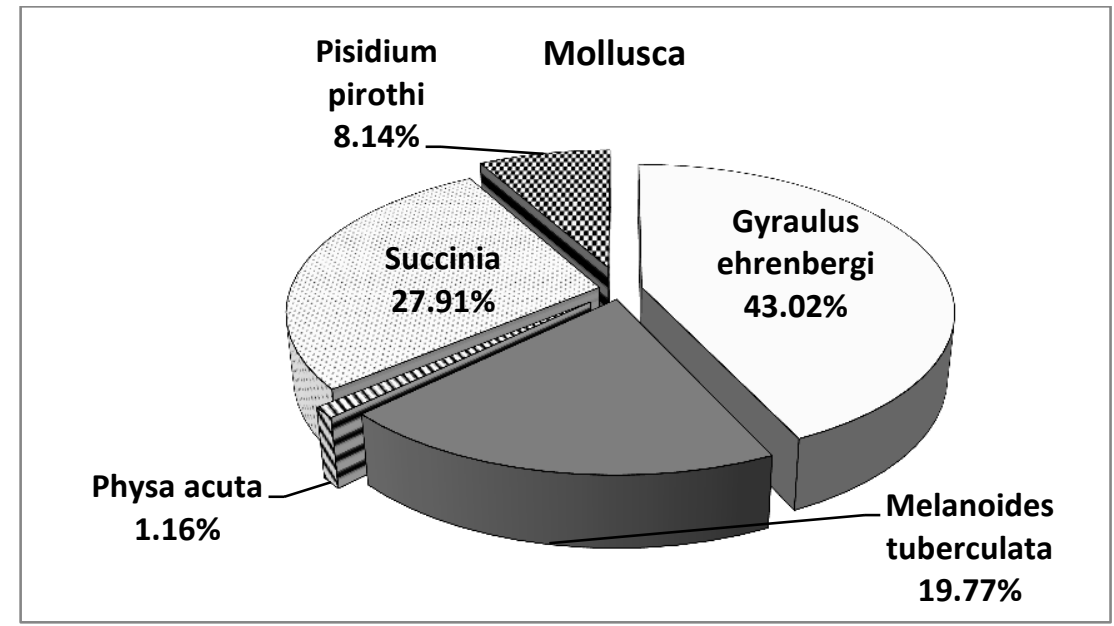

Fig. 8. Community structure of Mollusca in Lake Nasser in 2019 


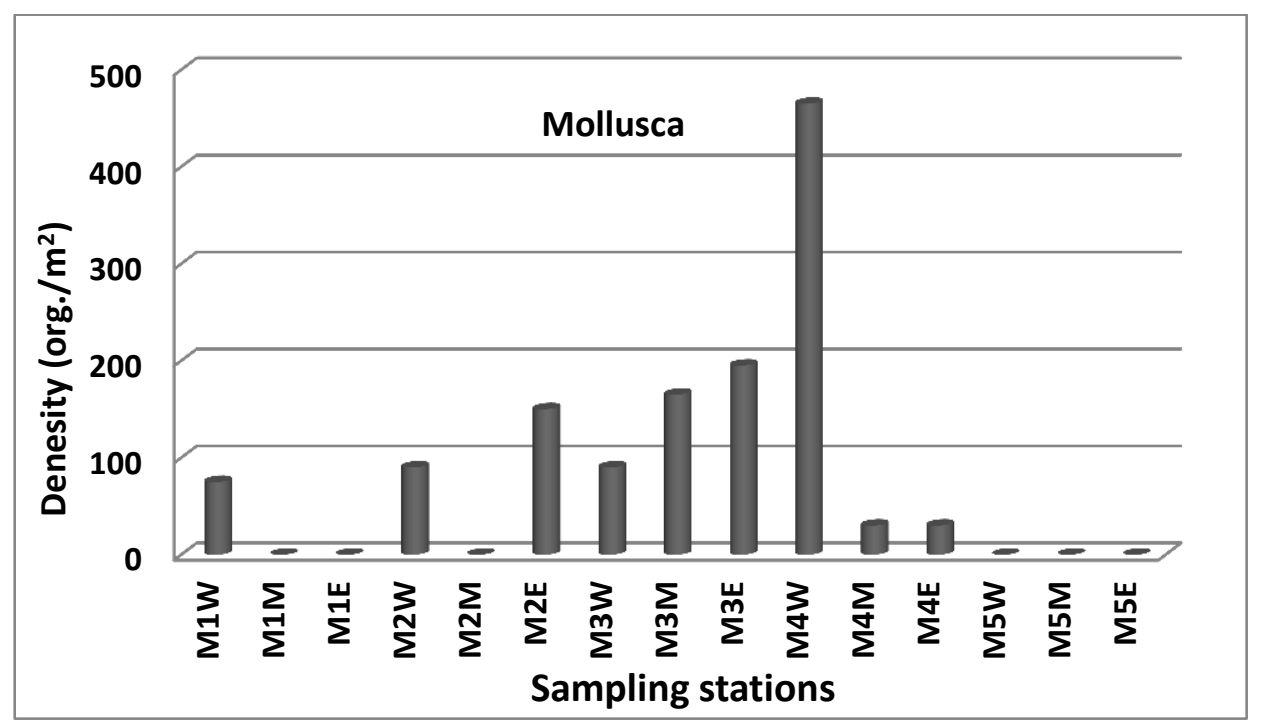

Fig. 9. Spatial distribution of Mollusca in Lake Nasser during March and July 2019

Table 2. Seasonal variation of macrobenthos in Lake Nasser during March and July 2019

\begin{tabular}{|c|r|c|r|}
\hline & March & July & Average \\
\hline Mollusca & & & \\
\hline Gyraulusehrenbergi & 56 & 18 & 37 \\
\hline Melanoidestuberculata & 10 & 24 & 17 \\
\hline Physaacuta & 2 & 0 & 1 \\
\hline Succinia & 2 & 46 & 24 \\
\hline Pisidiumpirothi & 0 & 14 & 7 \\
\hline Subtotal & $\mathbf{7 0}$ & $\mathbf{1 0 2}$ & $\mathbf{8 6}$ \\
\hline Arthropoda & & & \\
\hline ChironomusLarvae & 44 & 154 & 99 \\
\hline Cricotopussp. & 0 & 34 & 17 \\
\hline Nymphoflschneura & 0 & 2 & 1 \\
\hline Pupa of Chironomidae & $\mathbf{2 8}$ & 4 & 16 \\
\hline Subtotal & $\mathbf{7 2}$ & $\mathbf{1 9 4}$ & $\mathbf{1 3 3}$ \\
\hline Annelida & & & \\
\hline Lymnodrillus spp. & 386 & $\mathbf{9 0 2}$ & 644 \\
\hline Total & $\mathbf{5 2 8}$ & $\mathbf{1 1 9 8}$ & $\mathbf{8 6 3}$ \\
\hline \multicolumn{2}{|r|}{}
\end{tabular}

\section{Macrobenthos diversity}

A healthy ecosystem and rich biodiversity increase ecosystem productivity, as each species in an ecosystem has a specific role and protects freshwater resources. Therefore, the decreased species number is considered as loss of biodiversity in polluted ecosystems that lead to habitat destruction. Three stations represented the highest species diversity in Lake Nasser, and therefore, reflect the best environment for the organisms to live in (Table 3). The western station 
of EL Madiq sector revealed the highest Shannon Weaver diversity index $\left(\mathrm{H}^{\prime}=1.55\right)$. It could be attributed to the dominance of 4 species of arthropods, and exclusively, the dominance of nymph of Ischneura. This may reflect the good water condition at this sector. This result is followed by the eastern part of Wadi Abyad sector and the western part of Tushka,which revealed 1.23 and 1.09 of Shannon Weaver index, respectively.On the contrary, the middle stations of Wadi Abyad and Aswan sectors recorded the least diversity Shannon Weaver index value $\left(H^{\prime}=0.21\right.$ and 0.27 , respectively). This finding may be due to the nature of the sediment which led to the absence of all mollusc species and the presence of one Annelida species (Limnodrilus sp.) and one Insecta species (Chironomuslarvae). However, the dominance of Limnodrilus sp. and Chironomus larvae with the absence of all other species has been used to indicate a poor water quality which is confirmed by Brinkhurst (1974) who mentioned that, the monogeneric assemblage of tubificid worms, with the dominance of Limnodrilushoffmeisteri indicates that the water stream is somewhat gross organic polluted and eutrophic.

Table 3. Species diversity of benthic macroinvertebrate in different stations during the study period

\begin{tabular}{|c|c|c|c|c|c|c|}
\hline Station & $\mathbf{S}$ & $\mathbf{N}$ & $\mathbf{d}$ (Richness) & J' (Evenness) & $\begin{array}{c}\text { H'(log) } \\
\text { (Shannon) }\end{array}$ & $\begin{array}{c}\text { 1-lambda } \\
\text { Simpson }\end{array}$ \\
\hline St.1 E & 3 & 180 & 0.39 & 0.81 & 0.89 & 0.54 \\
\hline St.1 M & 2 & 975 & 0.15 & 0.39 & 0.27 & 0.14 \\
\hline St.1 W & 5 & 1260 & 0.56 & 0.60 & 0.97 & 0.56 \\
\hline St.2 E & 7 & 720 & 0.91 & 0.63 & 1.23 & 0.56 \\
\hline St.2 M & 2 & 270 & 0.18 & 0.31 & 0.21 & 0.11 \\
\hline St.2 W & 5 & 510 & 0.64 & 0.61 & 0.98 & 0.48 \\
\hline St.3 E & 5 & 735 & 0.61 & 0.64 & 1.02 & 0.52 \\
\hline St.3 M & 4 & 270 & 0.54 & 0.71 & 0.98 & 0.55 \\
\hline St.3 W & 6 & 330 & 0.86 & 0.87 & 1.55 & 0.76 \\
\hline St. 4 E & 5 & 1740 & 0.54 & 0.41 & 0.65 & 0.32 \\
\hline St.4 M & 3 & 810 & 0.30 & 0.29 & 0.32 & 0.14 \\
\hline St.4 W & 7 & 1470 & 0.82 & 0.56 & 1.09 & 0.54 \\
\hline St.5 E & 2 & 1455 & 0.14 & 0.67 & 0.46 & 0.29 \\
\hline St.5 M & 2 & 1665 & 0.13 & 0.47 & 0.32 & 0.18 \\
\hline St.5 W & 3 & 555 & 0.32 & 0.38 & 0.42 & 0.20 \\
\hline
\end{tabular}

Macrobenthic fauna is considered a good indicator for the biological and environmental status of the aquatic ecosystem. To examine the associations between the population density and the stations, Primer Similarity Index was applied to the data and is presented as a dendrogram in Fig. (10). It is clear that there were 2 clusters of stations. The first cluster was composed of Abu Simble sector, the middle and eastern stations of Tushka sector, and the middle stations of both Aswan and Wadi Abyad sectors. It could be attributed to the factor of low diversity index in these stations. The second cluster was characterized by higher biodiversity mostly in the northeastern and western stations (Aswan, Wadi Abyad, and El-Madiq). 


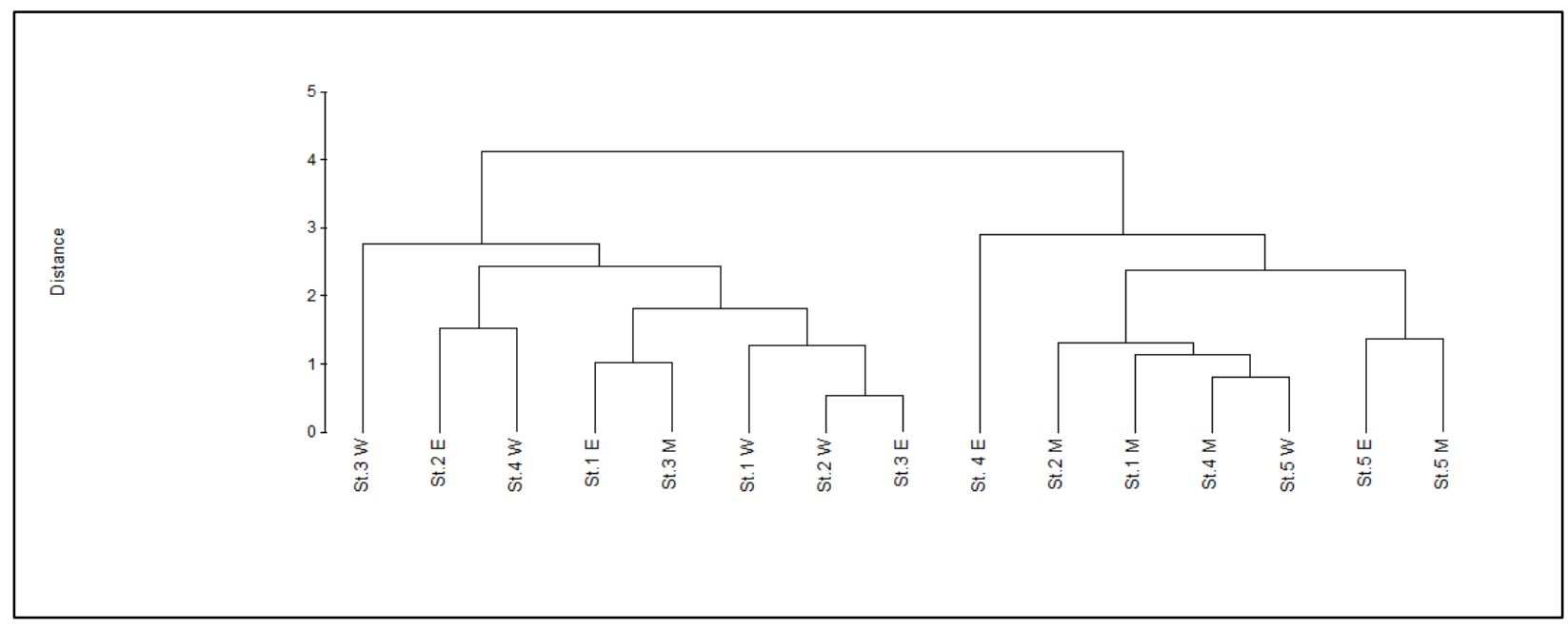

Fig. 10. Dendrogram showing similarity among the 15 studied stations in Lake Nasser according to macrobenthic community structure

\section{Long-term changes of macrobenthic invertebrates' community structure}

Obviously, macrobenthic invertebrates are greatly influenced by complex interrelationship between biotic and abiotic factors. In the present investigation, oligochaetes were the most abundant group where the decaying detritus and macrophytes provide the bottom with nutrientsmaintainig good nourishment.

Historically, the Lake's old bed was inhabited by a very dense population of bivalves. During the stagnation period, with the formation of the lake, these bivalves died and disappeared. Since 1973, oligochaetes and mussels resettled in the shallow inlet water of the khors due to the presence of favorable oxygen conditions (Entz 1978).

As shown in Table (3), the number of species decreased dramatically to only 9 species compared to $15,43,39$, and 24 in 1987, 1993, 1995 and 2013, respectively. This could be related to anthropogenic impacts (Elewa, 1987; Iskaros, 1988, 1993; Fishar, 1995; Abdel-Gawad \& Mola, 2014).

Furthermore, the standing crop of macrobenthic fauna in Lake Nasser was $863 \mathrm{org} . / \mathrm{m}^{2}$ compared to $823 \mathrm{org} . / \mathrm{m}^{2}$ in 1995 , and $529 \mathrm{org} . / \mathrm{m}^{2}$ in 2013 (Table 3). Thus, it is clear that Lake Nasser has possessed the same composition of macrobenthic invertebrates since the 1980s till now, although the biodiversity and species richness have been declined to a great extent. Nassif (2012) deduced that the low species diversity and dominance of pollution- tolerant species (e.g. Limnodrilushoffmeisteri and Chironomus larvae) beside the disappearance of sensitive species indicate that the water quality of the lake has deteriorated.

\section{CONCLUSION}

In conclusion, the current study revealed that the macrobenthos biodiversity, as well as species richness in Lake Nasser, have shown a drastic decline from one year to another. Therefore, it is recommended to apply an effective legal framework and improve public awareness to maintain Lake Nasser healthy water. That is why this paper is an alarming tool for 
decision-makers and stakeholders to take the right action to mitigate the pollution resources discharging on one of the most important and historical lakes in Egypt.

Table 3. Checklist of benthic invertebrates recorded in Lake Nasser by different authors(+ $=$ Present,$\quad-=$ Not recorded)

\begin{tabular}{|c|c|c|c|c|c|}
\hline Taxa and species & Elewa (1987) & $\begin{array}{c}\text { Iskaros } \\
(1988 \& \text { 1993) }\end{array}$ & $\begin{array}{l}\text { Fishar } \\
\text { (1995) }\end{array}$ & $\begin{array}{c}\text { Abdel- } \\
\text { Gawad\&Mola }\end{array}$ & Present study \\
\hline \multicolumn{6}{|l|}{ Phylum : Cnidaria } \\
\hline \multicolumn{6}{|l|}{ Class : Hydrozoa } \\
\hline Hydra vulgaris Pallas, 1766 & - & - & + & - & - \\
\hline \multicolumn{6}{|l|}{ Phylum : Bryozoa } \\
\hline \multicolumn{6}{|l|}{ Class : Phyleclolaemata } \\
\hline Fredericella sultana (Blumenbach, 1779) & - & - & + & - & - \\
\hline \multicolumn{6}{|l|}{ Phylum : Arthropoda } \\
\hline \multicolumn{6}{|l|}{ Class : Insecta } \\
\hline Ablabesmyia sp. & - & + & + & - & - \\
\hline Caenis sp. & - & - & + & - & - \\
\hline Chironomus sp. & - & + & + & + & + \\
\hline Circotopus sp. & - & + & + & - & + \\
\hline Clinotanpus sp. & + & + & - & - & - \\
\hline Coelotanpus sp. & - & + & + & - & - \\
\hline Conchopelopia sp. & - & + & - & - & - \\
\hline Cryptochironomus sp. & + & + & + & + & - \\
\hline Dicrotendipesmodestus & - & + & - & - & - \\
\hline Einfeldina sp. & - & + & - & - & - \\
\hline Enallagma sp. & - & - & + & - & - \\
\hline Gomphus sp. & - & + & - & - & - \\
\hline Ischnura sp. & - & - & + & + & + \\
\hline Libellula sp. & - & + & - & - & - \\
\hline Microchironomus sp. & - & + & - & - & - \\
\hline Micronectaplicata & - & - & + & - & - \\
\hline Microtendipes sp. & + & + & + & - & - \\
\hline Neurocordula sp. & - & - & + & - & - \\
\hline Nilodorum sp. & - & + & + & - & - \\
\hline Pelopia sp. & - & + & - & $=$ & - \\
\hline Plathemis sp. & - & - & + & - & - \\
\hline Polypedilum sp. & - & + & + & + & - \\
\hline Perithemissp. & - & + & + & + & - \\
\hline Procladius sp. & + & + & + & - & - \\
\hline Pseudoagrionniloticus & - & + & - & - & - \\
\hline Tanpus sp. & - & + & - & - & - \\
\hline Dytiscide sp. & - & - & + & - & - \\
\hline Tanytarsus sp. & + & + & + & + & - \\
\hline Hydrovatus sp. & - & - & + & + & - \\
\hline Larvae of Trichoptera & + & + & + & + & - \\
\hline Pupae of Chironomidae & - & - & - & + & + \\
\hline Nymphs of Ephemeroptera & - & + & - & - & - \\
\hline Adult of Corixidae & - & + & - & - & - \\
\hline \multicolumn{6}{|l|}{ Class : Crustacea } \\
\hline Cardinanilotica(P. Roux, 1833) & - & - & + & - & - \\
\hline Chlamydothecaunispinosa, Baird, 1862 & - & - & + & + & - \\
\hline
\end{tabular}




\begin{tabular}{|c|c|c|c|c|c|}
\hline Potamonautesniloticus (H. Milne Edwards) & - & - & - & - & . \\
\hline Stenocyprismalcolmsoni Baired, 1862 & - & - & + & - & - \\
\hline \multicolumn{6}{|l|}{ Phylum : Annelida } \\
\hline \multicolumn{6}{|l|}{ Class : Oligochaeta } \\
\hline BranchiurasowerbyiBeddard, 1892 & + & + & + & + & - \\
\hline LimnodrilushoffmeisteriClaparéde, 1862 & + & + & + & + & + \\
\hline LimnodrilusudekemianusClaparéde, 1862 & + & + & + & + & - \\
\hline Pristina sp. & - & - & + & + & - \\
\hline \multicolumn{6}{|l|}{ Class : Hirudinea } \\
\hline Helobdellaconifera (Moore, 1933) & - & + & + & + & - \\
\hline \multicolumn{6}{|l|}{ Phylum: Mollusca } \\
\hline \multicolumn{6}{|l|}{ Class : Gastropoda } \\
\hline Bellamya unicolor (Olivier, 1804) & - & + & - & - & - \\
\hline Biomphalariaalexandrina (Ehrenberg, 1831) & - & + & - & - & - \\
\hline Bulinustruncatus (Audouin, 1827) & + & + & + & + & - \\
\hline Bulinusforskalii (Ehrenberg, 1831) & - & + & - & - & - \\
\hline Cleopatra bulimoides (Olivier, 1804) & - & + & + & + & - \\
\hline Gabbiellasenaariensis (Kuster, 1852) & - & + & - & - & - \\
\hline Helisomaduryi (Wetherbg, 1879) & - & + & - & - & - \\
\hline Lanistescarinatus (Olivier, 1804) & - & + & - & - & - \\
\hline Lymnaeanatalensis, Krauss, 1848 & - & + & - & - & - \\
\hline Melanoidestuberculata (Müller, 1774) & + & + & + & + & + \\
\hline Physaacuta Darparnaud, 1805 & + & + & + & + & + \\
\hline Pila ovata (Olivier, 1804) & - & + & - & - & - \\
\hline Segmentorbisangustus (Jickeli, 1874) & - & + & - & - & - \\
\hline Theodoxusniloticus (Reeve, 1856) & - & + & - & - & - \\
\hline Valvata nilotica Jickeli, 1874 & + & + & + & + & - \\
\hline Gyraulusehrenbergi (Beck, 1837) & - & - & + & + & + \\
\hline \multicolumn{6}{|l|}{ Class : Bivalvia } \\
\hline Corbiculaconsobrina (Cailliaud, 1827) & + & - & + & + & - \\
\hline Pisidium pirothi Jickeli, 1881 & + & - & + & + & + \\
\hline Euperaferruginea (Krauss, 1848) & - & - & + & - & - \\
\hline Total & 15 & 43 & 39 & 24 & 9 \\
\hline
\end{tabular}

\section{Acknowledgments}

The current study was a part of the project entitled 'Environmental Monitoring and Fisheries Development of Lake Nasser- towards sustainable development', which was funded by the National Institute of Oceanography and Fisheries (NIOF) of Egypt. The physicochemical parameters measured in this study were provided by the chemistry laboratory, Freshwater and Lakes Division of NIOF.

\section{REFERENCES}

Abd El-Monsef, H.; Smith, S.E. andDarwish, K. (2015).Impacts of the Aswan High Dam after 50 years. Water ResourManag,29(6):1873-1885. 
Abdel-Gawad, S.S. (2016). Impact of some physico-chemical factors of water on the diversity and distribution of Mollusca in Lake Nasser (Egypt). Egypt. J. Aquat. Biol. \& Fish., 20(3): 89- 101.

Abdel-Gawad, S.S. and Abdel-Aal, E.I. (2018). Impact of Flood Cycle on Phytoplankton and Macroinvertebrates Associated with Myriophyllumspicatumin Lake Nasser Khors (Egypt). J. Biol. Sci., 18: 51- 67.

Abdel-Gawad, S.S. andMola, H.R. (2014). Macrobenthic invertebrates in the main channel of Lake Nasser, Egypt. Egypt. J. Aquat. Res., 40: 405- 414.

Abdo, M.H. (2003). Physico-chemical characteristic of Abu Zabaal ponds, Egypt.Egypt. J. Aquat. Res., 31 (2): 1- 15.

Abou El-Ella, S.M.; El Samman, A. (2010).Ecosystemstatus of the north part of Lake Nubia African. J Biol Sci.,6(2):7-21.

APHA (2005). American Water Works Association, Water Environment Federation. Standard Methods for the Examination of Water and Wastewater, 21th ed. American Public Health Association, Washington, DC. 2005.

Brinkhurst, R.O. (1974).The Benthos of Lakes. St. Martins Press, New York

Brown, D. S. (1980).Freshwater snails of Africa and their medical importance.Taylor and Francis.London, 487pp.

El Gamal, T. andZaki, N, (2017).Egyptian irrigation after the Aswan High Dam. Irrigated Agriculture in Egypt, 47-79

El Shemy, M. (2010).Water quality modeling of large reservoirs in semiarid regions under climate change-example Lake Nasser, Egypt.Dissertation, University of Echnische.

El-Shimy, N. A. (1994). A contribution to some leech fauna (Hirudinea) in the Middle East. J. Egyptian German Society of Zoology., 14: 13-27.

Elewa, A.A. (1987). Fish stock assessment in Lake Nasser. A Nile Project, Inst. Oceanogr. and Fish., Academy of Scientific Research and Technology, Cairo, A.R.E.

El-Shabrawy, G.M. and Abd El-Regal, R. (1999).Benthic fauna and sediment of Lake Nasser.I - Main channel and its littoral area. Bulletin of the Faculty of Sciences, Zagazig University,21: 193-215.

Entz, B. A. G. (1978). Sedimentation processes in the Reservoir Lake Nasser -Nubia during $1965-\cdot 1974$ and future aspects. Symposium of Ecological studies on the Nile River. Egyptian Society of Environment, Cairo.

Farhat, H.I. and Aly, W. (2018). Effect of site on sedimentological characteristics and metal pollution in two semi-enclosed embayments of great freshwater reservoir: Lake Nasser, Egypt. J Afr Earth Sci.,141: 194-206.

Fishar, M.R.A. (1995). Studies on bottom fauna in Lake Nasser, Egypt. Ph.D. Thesis, Suez Canal Univ., 267pp. 
Fishar, M.R.A. (2000).Macrobenthic fauna, pp. 75-79. In J.F. Craig (ed.), Sustainable Fish Production in Lake Nasser: Ecological Basis and Management Policy. ICLARM Conference Proceedings, 61: $184 \mathrm{pp}$.

Ibrahim, A. M.; Bishai, H. M. and Khalil, M. T. (1999).Freshwater mollusca of Egypt.Egyptian Environmental Affair Agency, publication of national biodiversity, unit number 10.

Iskaros, I.A. (1988). Biological studies on bottom fauna in Lake Nasser and adjacent waters.M.Sc. Thesis, Fac. Sci, Alexandria Univ., 184 pp.

Iskaros, I.A. (1993).Ecological studies on the distribution of zooplankton and bottom fauna in KhorKalabsha in Lake Nasser. Ph.D. Thesis, Fac. Sci, Mansoura Uni., 304 pp.

Iskaros, I.A.; Gindy, N.N. and EI Dardir, M. (2011).Long-term fluctuations of macrobenthic invertebrates in Aswan Water Reservoir, Egypt. Inter. J. Environ. Sci. Eng. Vol.1: 37-48

Iskaros, I.A. and El Dardir, M. (2010).Factors affecting the distribution and abundance of bottom fauna in Lake Nasser, Egypt. Nat. Sci.,8 (7): 95-110.

Iskaros, I.A. and Gindy, N.N. (2009). The effect of the substrate status on bottom fauna in Aswan reservoir, Egypt. Egypt. J. Aquat. Res.,35(2): 137-148.

Khalifa, N.; El-Damhogy, K.A.; Fishar, M.R.; Nasef, A.M. and Hegab, M.H. (2015).Using zooplankton in some environmental biotic indices to assess water quality of Lake Nasser, Egypt.Int J Fisheries Aquat Stud.,2(4): 281-289

Latif, A.F.A. (1974). Fisheries of Lake Nasser and Lake Nubia. In:Report on Trip to Lake Nasser and Lake Nubia, by Entz, B. and Latif, A.F.A. Aswan regional planning. Lake Nasser development center, A.R.E., pp.64-137.

Latif, A.F.A.; El-Etreby, S.G.;Azim, M.E. and Sherie, H.A. (1979).Reservoir fishes and fisheries resources. Report on Surveys to Lake Nasser and River Nile Project. Academy of Scientific Research and Technology, Cairo, Egypt.

Mageed, A.A. and Heikal, M.T. (2006). Factors affecting seasonal patterns in epilimnion zooplankton community in one of the largest man-made lakes in Africa (Lake Nasser, Egypt). Limnologica, 36: 91- 97.

Mola, H.R. and Abdel-Gawad, S.S. (2014).Spatio-temporal variations of macrobenthic fauna in Lake Nasser khors, Egypt. Egypt. J. Aquat. Res.,40: 415- 423.

Nassif, M.G. (2012). Ecological studies on aquatic invertebrates of Ismailia Canal, Egypt. Ph.D. thesis, Fac. Science, Ain Shams Uni., 199 pp.

Nkwoji, J. A.; Yakub, A.; Ajani, G. E.; Balogun, K. J.; Renner, K. O.; Igbo, J. K.; Ariyo, A. A. and Bello, B. O. (2010).Seasonal variations in the water chemistry and benthic macroinvertebrates of a south western lagoon, Lagos, Nigeria.Journal of American Science.Vol. 6 (3): 85-92.

Ravera, O. (1998). Utility and limits of biological and chemical monitoring of the aquatic environment. Annal.Dichim.,88: 909-913. 
Ravera, O. (2000). Ecological monitoring for water body management. Proceedings of monitoring Tailormade III. International Workshop on Information for Sustainable Water Management, pp:157-167.

Ruffo, M. (1982).The Amphipoda of the Mediterranean.Mem. Del. Inst. Oceano., Monaco. Part I: Gammaridae.

Rosenberg, D.M.; Bilyj, B. and Wiens, A.P. (1984).Chironomidae (Diptera) emerging from the littoral zone of reservoirs, with special reference to southern Indian Lake, Manitoba. Can. J. Fish.Aquat. Sci., 41: 638-647.

Salih, S.Q.; Allawi, M.F.; Yousif, A.A.; Armanuos, A.M.; Saggi, M.K.; Ali, M. and Chau, K.W. (2019). Viability of the advanced adaptive neuro-fuzzy inference system model on reservoir evaporation process simulation: case study of Nasser Lake in Egypt. EngApplComput Fluid Mech.,13(1):878-891

Wahab, H.M.A.; Iskaros, I.A.; Fishar, M.R. and Mohamed, N.E. (2018).Ecological studies on macrobenthic invertebrates in four northern Khors of Lake Nasser (Egypt); Community Structure, Relative Abundance and Diversity. Egypt. J. Aquat. Biol. \& Fish., 22(3): 111- 124.

World Health Organization (WHO) (2003): $\mathrm{pH}$ in drinking-water. Background document for preparation of WHO Guidelines for drinking-water quality.Geneva, World Health Organization (WHO/SDE/WSH/03.04/12). 